\title{
Egyptian Pyramid Model Housing Enhancing the Compensatory Renal Growth in Nephrectomized Rats
}

\author{
Sohair Ramadan Fahmy*, Khadiga Gaafar, Dawlat Ahamed Sayed and Huda Nageeb \\ Department of Zoology, Cairo University, Egypt
}

Submission: November 07, 2016; Published: November 30, 2016

*Corresponding author: Sohair Ramadan Fahmy, Department of Zoology, Faculty of Science, Cairo University, Giza 12613, Egypt

Tel: 002/ 01149939166; E-mail: sohair@sci.cu.edu.eg

\begin{abstract}
The present study aims to evaluate the role of the Egyptian pyramids housing on the enhancement of reno-regenerative ability after unilateral nephrectomy in rats. Forty two male Wistar rats were assigned equally into three main groups (14 rats for each).The sham-operated control (sham group) and unilateral nephrectomized rats (Nx group). Both groups maintained in their home cages for 7 and 14 days. The third group(Pyramid housed group) in which Nx rats housed within the wooden pyramid (6 hr/day)for 7 and 14 days. The present study showed significant increase in size of the remaining kidney, rate of sodium excretion and marked increase in urea, uric acid and creatinine levels in the serum of Nx rats. In addition, significant decrease in renin-angiotensin-aldosterone system was also recorded following nephrectomy for 7 and 14 days. Pyramid environment reversed the actions of nephrectomy in rats and restored the kidney function near the sham levels. In conclusion: The present study recommends using pyramidal shapes for nephrectomized individual's rooms immediately following the surgery and during the recovery periods to avoid kidney impairment as consequence of nephrectomy process.
\end{abstract}

Keywords: Nephrectomy; Egyptian pyramid models; Electrolytes; Kidney functions; Renin-angiotensin-aldosterone system; Rats

\section{Introduction}

Chronic kidney disease (CKD) is a public health problem associated with considerable morbidity and mortality [1]. CKD defined as the presence of kidney damage, manifested by abnormal albumin excretion or decreased kidney function that quantified by glomerular filtration rate (GFR) measurement [2].The patients with reduced renal mass found evidence for lower glomerular filtration rate [3]. The impaired GFR in chronic kidney disease and the increased filtration load on the remnant glomeruli led to the increased excretion of ions and levels of creatinine in plasma $[4,5]$. So, kidney disease is conventionally assessed overall renal functions [6]. Chronic renal failure leads to progressive and irreversible destruction of nephron mass [7].

Nephrectomy may be done because of disease, cancer, injury or transplant donation. Nephrectomy is a surgical intervention having first been introduced for the treatment of localized renal cell carcinoma [8]. Although surgical resection remains the standard of care in the treatment of small renal masses, nephrectomy is also a recognized risk cause for developing CKD [9]. Among the available experimental models for CKD, unilateral nephrectomy (UNx) has been a standard experimental model to study the progressive renal disease $[10,11]$. Unilateral nephrectomy usually followed compensatory increase in the size of the remaining kidney and increases in glomerular filtration rate [12].

The renin-angiotensin-aldosterone system (RAAS) regulates renal vasomotor activity, maintains optimal salt and water homeostasis, and controls tissue growth in the kidney [13]. RAAS has been implicated as a key player in the pathogenesis of renal diseases [14]. Recently, Kelly et al. [15] provide strong evidence for the role of the RAAS in CKD progression.

The Pyramids of Egypt are one of the world's most amazing achievements which claimed man's attention and planned with mathematical and geometrical precision $[16,17]$. Pyramid research proves evidence that the space within the great pyramid generates energy of the electromagnetic spectrum and other forms or degrees of the so-called universal energy [18]. Models with the same dimensions of the great pyramid of Giza are believed to generate, transform and transmit energy when aligned on a true north south axis [19]. It has been reported that, pyramid models promote greater relaxation, better 
wound healing in rats, and protection against stress-induced neurodegenerative changes in mice [20].

So, the present study aims to evaluate the role of the Egyptian pyramids housing on the enhancement of reno-regenerative ability after unilateral nephrectomy in rats.

\section{Materials and methods}

\section{Pyramid model design and dimensions}

A wooden pyramid model of $30 \mathrm{in}$. height, $45 \mathrm{in}$. base and 41.5 sides was fabricated locally and used during the present [21]. Holes were drilled on all sidewalls for ventilation. A fixed glass window was provided for observation. The 4 sides of the pyramid were positioned to face north, south, east and west, the corners aligned with north west, south west, north east, and south east [22]. The four triangular sides of the pyramid met at the apex and rested on the base (Figure 1).

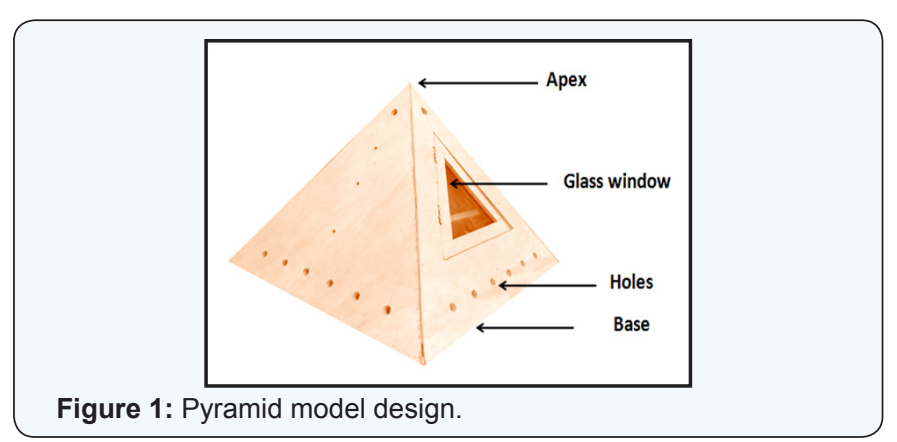

\section{Experimental animals}

Forty two healthy male Wistar albino rats (Rattus norvegicus), weighing 180-200g, were used. The animals were obtained from the National Research Center (NRC), Egypt. Animals were grouped and housed in polypropylene cages (five animals per cage) in the well ventilated animal house in air conditioned room at temperature of $23 \pm 2{ }^{\circ} \mathrm{C}$ and under natural day and night cycle. All of them were feed standard chow pellets and drinking water. The rats were kept for a week before the commencement of the experiment for acclimatization. The experimental protocol was approved by the Institutional Animal Care and Use Committee (IACUC) (CUFS/S/PHY/15/14) of Faculty of Science, Cairo University, Egypt.

\section{Unilateral nepherectomy}

Unilateral nepherectomy was done according to Chen et al. [23]. Rats were anesthetized with sodium pentobarbital (50 $\mathrm{mg} / \mathrm{kg}$ body weight; ip). Laparatomy was done under antiseptic conditions. A small longitudinal incision was made and the left kidney was removed (Nx group) and the abdominal incision was closed using a 4-0 silk thread (Figure 2). In sham-operated animals, the left kidney was exposed and gently manipulated but left intact (sham group). All animals received normal saline of equal volume at corresponding time points. During the operation, body temperature of the rats was maintained at $36.5^{\circ} \mathrm{C}$ to 37.5
${ }^{\circ} \mathrm{C}$. All the rats received $50 \mu \mathrm{l}$ of $0.2 \%$ ropivacaine subcutaneously for the post-operative analgesia.

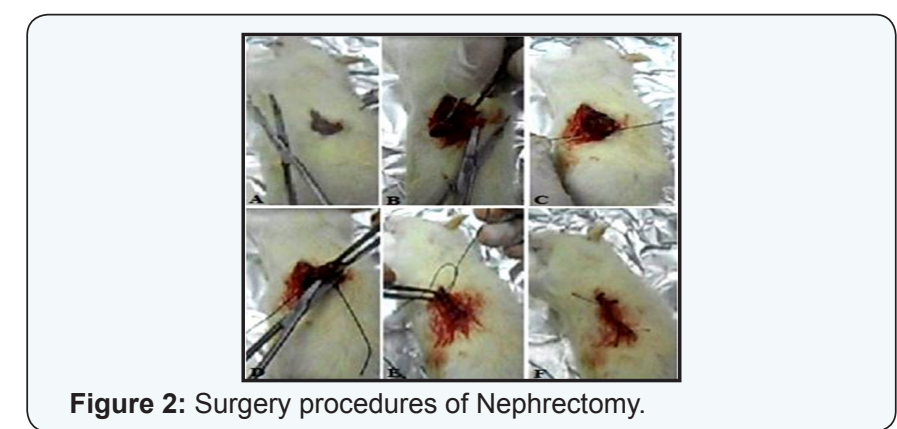

\section{Experimental design}

Fourty two male Wistar rats were assigned equally into three main groups (14 rats for each).The sham-operated control (sham group) and unilateral nephrectomized rats (Nx group). Both groups maintained in their home cages for 7 and 14 days. The third group (Pyramid housed group) in which Nx rats housed within the wooden pyramid ( $6 \mathrm{hr} /$ day) for 7 and 14 days [24].

\section{Animals handling}

At the end of each experimental period, the rats were transferred to individual metabolic cages for $24 \mathrm{~h}$ to collect urine. During this time, the rats had free access to water. Animals were euthanized under deep anesthesia with sodium pentobarbital and sacrificed by cardiac puncture. Blood was collected in centrifuge tubes. Right kidney was removed and immediately blotted using filter paper to remove traces of blood and weighted then suspended in $10 \%$ formal saline for fixation preparatory to histological processing.

\section{Sample preparation}

Urine preparation: The collected urine samples were freed from fecal contamination and the urine volume was measured by using the measuring cylinder. The urine samples were centrifuged for 10 minutes and the urine supernatant was then stored at $-70^{\circ} \mathrm{C}$ until analysis.

Serum preparation: Blood samples collected in centrifuge tubes were centrifuged at $3000 \mathrm{rpm}$ for 20 minutes. Serum, stored at $-20^{\circ} \mathrm{C}$ until for biochemical and hormonal assays.

\section{Determination of electrolytes in urine and serum samples}

The appropriate kits (Bio-Diagnostic, Dokki, Giza, Egypt) were used to the determination of sodium ion by colorimetric method according to the method described by Trinder [25]. Potassium ion is determined using a colorimetric end point method according to the method of Sunderman and Sunderman [26]. Calcium was determined by colorimetric method using Biodiagnostic kits, according to the method described by Gindelar \& king [27]. 


\section{Determination of renal function in urine and serum samples}

Total protein was determined by colorimetric method using Bio-diagnostic kits, according to the method described by Gornal et al. [28]. Urea was determined by urease-Berthelot method using Bio-diagnostic kits, according to the method described by Fawcett \& Soctt [29]. Uric acid was determined by enzymatic colorimetric method using Bio-diagnostic kits, according to the method described by Barham \& Trinder [30]. Creatinine was determined by colorimetric method (End Point) using Bio-diagnostic kits, according to the method described by Schirmeister et al. [31]. Creatinine Clearance was determined according to the following equation:

Creatinine Clearance $(\mathrm{ml} / \mathrm{min})=\mathrm{mg}$ creatinine $/ \mathrm{dl}$ urine $\times \mathrm{ml}$ urine / 24 hrs

mg creatinine / dl serum $\times 1440$

\section{Hormonal assessment}

Plasma levels of renin, angiotensin and aldosterone were determined using mouse/rat ELISA kits (Cat\# SL0617Ra, SL0061Ra and SL0040Ra, respectively, Sunlong Biotech Co. LTD).

\section{Histopathological studies}

The fixed kidneys were embedded with paraffin blocks and microscopic specimens were sliced, and then subjected to hematoxylin and eosin stain according to Banchroft et al. [32] for histo-pathological examinations through the light microscope.

\section{Statistical analyses}

The data of the present study were analyzed statistically according to Shapiro-Wilk and Kolmogorov analysis. All the raw data were normally distributed and consequently all the statistical analysis done on the bases of the parametric analysis. Values were expressed as mean \pm SEM. To evaluate differences among the groups studied, one way analysis of variance (ANOVA) with the Duncan post hoctest was used in comparison of the group means and $p<0.05$ was considered statistically significant. SPSS for Windows (version 15.0) was used to the statistical analysis.

\section{Results}

The potency of Egyptian pyramid housing on right kidney and urine volume in nephrectomized rats $(\mathrm{Nx})$

Data recorded in (Figure 3), clearly showing significant increase $(\mathrm{P}<0.05)$ in the weight of the right kidney in $\mathrm{Nx}$ rats either housed in the home cage or in the Egyptian pyramid model in comparison to sham group following 7 and 14 days of nephrectomy, respectively. However, the increase in weight of the remaining kidney was more pronounced following housing $\mathrm{Nx}$ rats in the Egyptian pyramid model. The recorded results also revealed significant reduction $(\mathrm{P}<0.05)$ in the urine volume following nephrectomy. Housing rats for 14 days in the Egyptian pyramid model induced marked increase in the urine volume (Figure 3).

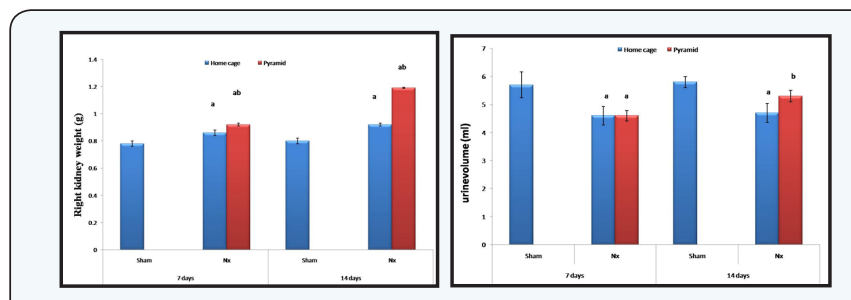

Figure 3: The Ameliorative potency of the Egyptian pyramid housing on weight of right kidney and urine volume in nephrectomized rats $(\mathrm{Nx})$.

Values are means \pm SEM ( $n=7$ per group).

a: Significant at $(P<0.05)$ as compared to the corresponding sham group.

b: Significant at $(P<0.05)$ as compared to the corresponding home cage group.

The potency of Egyptian pyramid housing on some electrolytes in nephrectomized rats $(\mathrm{Nx})$

Unilateral nephrectomy induced significant $(\mathrm{P}<0.05)$ increase in the urine sodium and calcium levels concomitant with marked decrease of their serum levels in comparison to sham group (Figure 4,5). However, housing of Nx rats in the Egyptian pyramid for 7 and 14 days induced significant $(\mathrm{P}<0.05)$ decrease in the urine sodium and calcium levels with increase in their serum level in comparison to $\mathrm{Nx}$ rats that housed in home cage. Levels of urine and serum potassium ions did not significantly

changed following nephrectomy for 7 and 14 days in comparison to sham groups (Figure 4,5). Housing of nephrectomized rats in the Egyptian pyramid for 14 days significantly $(\mathrm{P}<0.05)$ increased potassium ions excretion in urine (Figure 4).
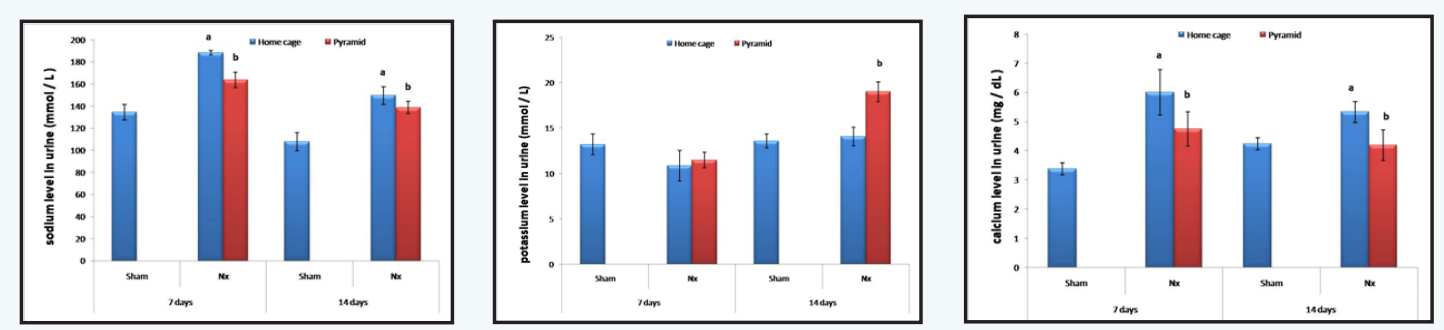

Figure 4: The Ameliorative potency of the Egyptian pyramid housing on some urine electrolytes concentrations in nephrectomized rats (Nx). Values are means \pm SEM ( $n=7$ per group).

a: Significant at $(\mathrm{P}<0.05)$ as compared to the corresponding sham group.

b: Significant at $(P<0.05)$ as compared to the corresponding home cage group. 

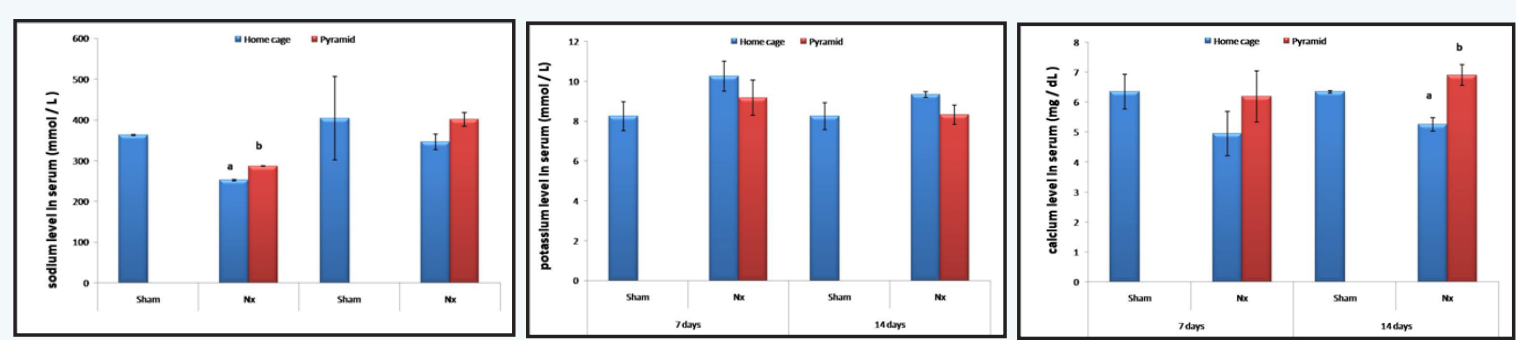

Figure 5: The Ameliorative potency of the Egyptian pyramid housing on some serum electrolytes concentrations in nephrectomized rats (Nx).

Values are means \pm SEM ( $n=7$ per group).

a: Significant at $(\mathrm{P}<0.05)$ as compared to the corresponding sham group.

b: Significant at $(P<0.05)$ as compared to the corresponding home cage group.

The potency of Egyptian pyramid housing on urine and serum kidney functions in nephrectomized rats (Nx)

Table1 demonstrated marked increase in protein uria with concomitant significant decrease $(\mathrm{P}<0.05)$ in total protein level in the serum in home cage $\mathrm{Nx}$ group in comparison to sham group. The obtained data also showed marked decrease in the levels of urine urea, uric acid and creatinine in home cage $\mathrm{Nx}$ rats as compared to sham group (Table 1) (Figure 6). On the other hand, their levels increased significantly in the $\operatorname{serum}(\mathrm{P}<0.05)$ of home cage Nx rats. However, housing of rats in the Egyptian pyramids for 7 and 14 days significantly $(\mathrm{P}<0.05)$ ameliorate these effects and restore their levels towards the control values (Table 1) (Figure 6). Creatinine clearance increased significantly $(\mathrm{P}<0.05)$ after nephrectomy for 14 days (Figure 7). However, housing of Nx rats in the Egyptian pyramid for 7 and 14 days induced significant increase in creatinine clearance (Figure 7).

Table 1: The Ameliorative potencyof the Egyptian pyramid housing on urine and serum kidney functions in nephrectomized rats (Nx)

\begin{tabular}{|c|c|c|c|c|c|}
\hline \multirow{2}{*}{ Parameter } & \multirow{2}{*}{$\begin{array}{c}\text { Time periods } \\
\text { (Days) }\end{array}$} & & \multirow{2}{*}{ Sham } & \multicolumn{2}{|c|}{$\mathbf{N x}$} \\
\hline & & & & Home cage & Pyramid \\
\hline \multirow{4}{*}{$\begin{array}{l}\text { Protein } \\
\text { (g/dl) }\end{array}$} & \multirow{2}{*}{7} & Urine & $4.03 \pm 0.43$ & $5.96 \pm 0.82$ & $4.69 \pm 0.71$ \\
\hline & & Serum & $7.05 \pm 0.64$ & $5.27 \pm 0.24^{\mathrm{a}}$ & $6.89 \pm 0.27^{b}$ \\
\hline & \multirow{2}{*}{14} & Urine & $3.98 \pm 0.06$ & $5.20 \pm 0.50^{\mathrm{a}}$ & $4.33 \pm 0.45$ \\
\hline & & Serum & $7.00 \pm 0.23$ & $5.24 \pm 0.12^{\mathrm{a}}$ & $8.26 \pm 0.60^{b}$ \\
\hline \multirow{4}{*}{$\begin{array}{c}\text { Urea } \\
\text { (mg/dl) }\end{array}$} & \multirow{2}{*}{7} & Urine & $9.87 \pm 1.35$ & $7.80 \pm 0.75$ & $10.20 \pm 0.89$ \\
\hline & & Serum & $4.21 \pm 0.41$ & $7.30 \pm 0.30^{\mathrm{a}}$ & $6.53 \pm 0.59^{b}$ \\
\hline & \multirow{2}{*}{14} & Urine & $16.73 \pm 0.06$ & $8.67 \pm 0.26 \mathrm{a}$ & $10.77 \pm 0.75 b$ \\
\hline & & Serum & $3.30 \pm 0.38$ & $6.95 \pm 0.15 a$ & $5.34 \pm 0.28 \mathrm{~b}$ \\
\hline \multirow{4}{*}{$\begin{array}{l}\text { Uric acid } \\
(\mathrm{mg} / \mathrm{dl})\end{array}$} & \multirow{2}{*}{7} & Urine & $119.60 \pm 8.14$ & $116.00 \pm 9.12$ & $124.80 \pm 8.14$ \\
\hline & & Serum & $5.37 \pm 0.25$ & $7.84 \pm 0.64 \mathrm{a}$ & $6.00 \pm 0.33 \mathrm{~b}$ \\
\hline & \multirow{2}{*}{14} & Urine & $120.00 \pm 15.49$ & $117.14 \pm 3.64^{\mathrm{a}}$ & $127.14 \pm 4.16^{b}$ \\
\hline & & Serum & $5.32 \pm 0.25$ & $7.34 \pm 0.07^{a}$ & $5.06 \pm 0.54^{b}$ \\
\hline
\end{tabular}

Values are means \pm SEM ( $n=7$ per group).

a: Significant at $(p<0.05)$ as compared to the corresponding sham group

b: Significant at $(p<0.05)$ as compared to the corresponding home cage group.

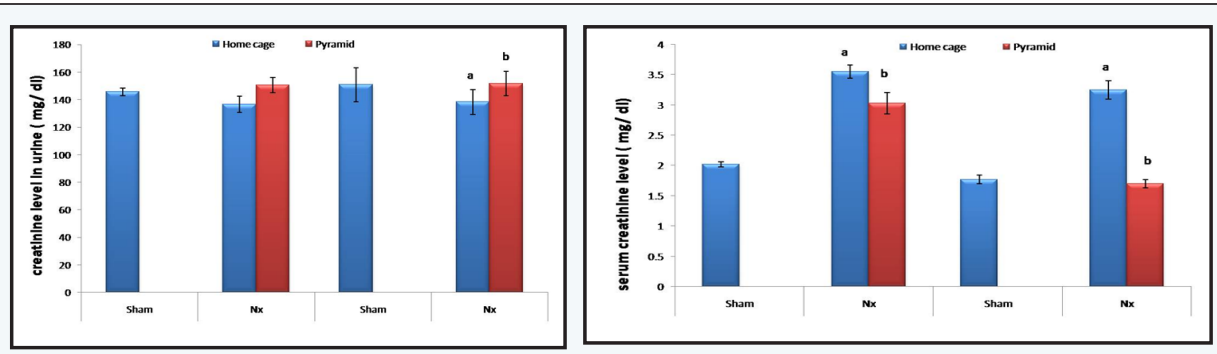

Figure 6: The Ameliorative potency of the Egyptian pyramid housing on urine and serum creatinine levels in nephrectomized rats ( $\mathrm{Nx}$ ). Values are means \pm SEM ( $n=7$ per group).

a: Significant at $(\mathrm{P}<0.05)$ as compared to the corresponding sham group.

b: Significant at $(P<0.05)$ as compared to the corresponding home cage group. 


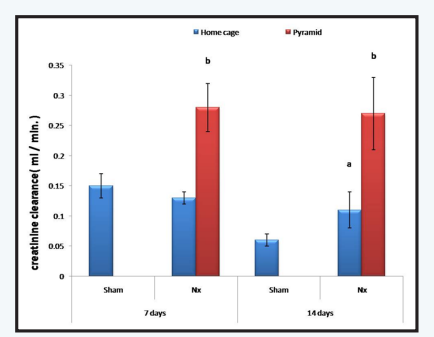

Figure 7: The Ameliorative potency of the Egyptian pyramid housing on creatinine clearance in nephrectomized rats $(\mathrm{Nx})$. Values are means \pm SEM ( $n=7$ per group).

a: Significant at $(P<0.05)$ as compared to the corresponding sham group.

b: Significant at $(P<0.05)$ as compared to the corresponding home cage group.

The potency of Egyptian pyramid housing on reinin, angiotensin and aldosterone in nephrectomized rats (Nx)

Data illustrated in Table 2 showed significant decrease in the levels of serum reinin, angiotensin and aldosterone following unilateral nephrectomy in rats in comparison to sham group. Levels of the studied hormones significantly increased after housing Nx rats in the Egyptian pyramid for 7 and 14 days.

Table 2: The Ameliorative potency of the Egyptian pyramid housing on rennin, angiotensin and aldosterone levels in nephrectomized rats $(\mathrm{Nx})$

\begin{tabular}{|c|c|c|c|c|}
\hline \multirow{2}{*}{$\begin{array}{c}\text { Hormones } \\
\text { (mmol/l) }\end{array}$} & \multirow{2}{*}{$\begin{array}{c}\text { Time } \\
\text { periods } \\
\text { (D ays) }\end{array}$} & \multirow{2}{*}{ Sham } & \multicolumn{2}{|c|}{$\mathbf{N x}$} \\
\hline & & & Home Cage & Pyramid \\
\hline \multirow{2}{*}{ Renin } & 7 & $71.01 \pm 2.96$ & $62.80 \pm 0.95^{\mathrm{a}}$ & $77.35 \pm 2.30^{\mathrm{b}}$ \\
\hline & 14 & $52.35 \pm 5.62$ & $46.01 \pm 0.66^{\mathrm{a}}$ & $55.21 \pm 2.10^{\mathrm{b}}$ \\
\hline \multirow{2}{*}{ Angio-tensin } & 7 & $158.44 \pm 5.04$ & $113.76 \pm 3.96^{\mathrm{a}}$ & $144.59 \pm 9.02^{\mathrm{b}}$ \\
\hline & 14 & $157.92 \pm 10.13$ & $119.46 \pm 2.04^{a}$ & $137.16 \pm 1.15^{\mathrm{b}}$ \\
\hline \multirow{2}{*}{ Aldos-terone } & 7 & $143.12 \pm 3.04$ & $105.98 \pm 2.33^{\mathrm{a}}$ & $151.49 \pm 7.34^{\mathrm{b}}$ \\
\hline & 14 & $141.83 \pm 8.57$ & $133.94 \pm 12.45^{\mathrm{a}}$ & $173.12 \pm 14.68^{b}$ \\
\hline
\end{tabular}

Values are means \pm SEM ( $n=7$ per group).

a: Significant at $(p<0.05)$ as compared to the corresponding sham group.

b: Significant at $(p<0.05)$ as compared to the corresponding home cage group.

The potency of Egyptian pyramid housing on histological alteration in nephrectomized rats $(\mathrm{Nx})$

Microscopic examination of kidney in sham groups (Figure 8A\& 8B) showed normal appearance of the tissue where, glomeruli appear enclosed in the outer layer of Bowman capsules as dense tufts of capillaries. Dilated glomeruli were observed in nephrectomized groups either underwent nephrectomy for 7 or 14 days in comparison to their corresponding sham group (Figure 8C\& 8D). Housing of Nx rats for 7 and 14 days in the Egyptian pyramid model caused slightly tubular dilatation and failed to return the normal architecture of kidney tissues in comparison to their corresponding Nx group that housed in their home cages (Figure 8E\& 8F).

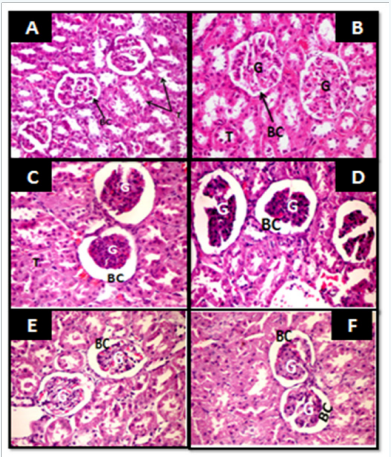

Figure 8: Histological study of hematoxylin\& eosin stained kidney sections $(400 \times)$ of sham rats $(A, B)$, rats underwent nephrectomy for 7 days and housed inside their home cages (C), rats underwent nephrectomy for 14 daysand housed inside their home cages (D), rats underwent nephrectomy and housed inside the Egyptian pyramid model for 7 days $(E)$ and rats underwent nephrectomy and housed inside the Egyptian pyramid model for 14 days (F). G: glomerulus, BC: Bowman's capsule, T: tubules.

\section{Discussion}

Chronic kidney disease (CKD) is a worldwide health threat associated with increased cardiovascular disease and mortality [33]. Ironically, although nephrectomy remains the standard of care in the treatment of small renal masses, it is also a recognized risk factor for developing CKD [9]. The present study searches for developing new strategy when applying unilateral nephrectomy in rats to avoid kidney injury. Research using Egyptian pyramids models have been shown that it promote greater relaxation and enhance tranquility in animals $[19,20]$. So, the present investigation postulated that housing of nephrectomized rats $(\mathrm{Nx})$ in a model of the Egyptian pyramid can help in the compensatory power of the remaining kidney.

Compensatory renal growth is a process of adaptation of the remaining kidney to the increased functional demand following unilateral nephrectomy (UNx). Following UNx the remaining kidney increases in size in response to hyper filtration and begins to compensate for its missing partner [34,35]. In conjunction with the reports of Morganand Ibrahim [36]; Gava et al. [5]; and Mjøen et al. [37], the present study recorded significant increase in the weight of right kidney following UNx in rats that may be interpreted as a compensatory response to the increased glomerular perfusion. These findings are supported by the histo-pathological investigation that showed marked dilatation of glomerulus and increase in Bowman space of the remnant kidney, compared with sham group. This increase was associated with enlargement and hypertrophy of the remaining kidney [38].

During diagnosis of kidney injury, the patient's electrolytes should be examined for secondary consequences of renal disease. The concentration of $\mathrm{Na}+$ and $\mathrm{K}+$ electrolytes in the extracellular fluid is maintained by the transport mechanisms occurring across the cell membranes and by the kidneys [39]. In agreement with the finding of Allison et al. [40], Gava et al. [5]; Bhadranna and Ahmed [41,42], the present study recorded 
significant rise in the rate of sodium excretion in $\mathrm{Nx}$ rats. This increase may be attributed to a decrease in the tubular sodium re-absorption. Diezi et al. [43], have also reported a decline in the fractional sodium reabsorption in proximal tubules and they convey it to glomerular imbalance, acting across proximal tubule. The decline in sodium re-absorption in proximal tubules in the present study can be confirmed by recorded decrease in its concentration in the serum. The concentrations of $\mathrm{K}+$ in urine and serum of $\mathrm{Nx}$ rats remained almost constant in comparison to sham control values. Similar studies reported earlier by Schultze et al. [44]; Bank and Aynedjian [45] and Bhadranna \& Ahmed $[41,42]$. Housing of $\mathrm{Nx}$ rats in the Egyptian pyramids enhance electrolytes levels in urine and serum suggesting its role in homeostasis in the body of $\mathrm{Nx}$ rats.

During the progression of the renal disease, loss of kidney function is accompanied by failing organ function leading to accumulation of a series of compounds [46]. Urea and creatinine are bio-indicators of the renal func $\neg$ tion [47], and the underlying presence of component(s) of the metabolic syndrome [48]. In consistent with the findings of Arya et al. [49]; Orsić et al. [50] and Gava et al. [5], the present investigation showed marked increase in urea, uric acid and creatinine levels in the serum of Nx rats. The elevation of the serum urea and creatinine concentrations following nephrectomy indicates a diminished impaired ability of the kidneys to filter these waste products from the blood and excrete them in urine. The present investigation showed the ameliorative efficacy of the Egyptian pyramid that may offer a suitable environment for healing mechanism restoring the kidney structure and function.

Determination of glomerular Filtration Rate (GFR) is almost the important parameter that could assess renal function. Glomerular filtration is the first step in urine formation and the GFR is about $20 \%$ of renal plasma flow. After removal of the renal tissue, GFR of the remaining kidney need to be increased to maintain fluid and electrolyte balance, through adjustments in vasomotor control of the microvasculature [51]. The renal clearance of endogenous creatinine is widely used to assess GFR and renal function in animal investigations [52]. In conjunction with the reports of Bohlouli et al. [53] and Chapman et al. [3], the present study revealed significant increase in creatinine clearance following unilateral nephrectomy in rats. Mueller \& Luyckx [54] reported increase in GFR by $60 \%-70 \%$ following uni-nephrectomy in the remaining kidney.

Renin-angiotensin system (RAS) plays a key role in the regulation of renal function, volume of extracellular fluid and blood pressure [55]. Studies indicate that an appropriate interaction between tubule glomerular feedback (TGF) and the renin-angiotensin system is essential for body fluid and electrolyte homeostasis [56]. The TGF feedback is a negativefeedback system operating within the juxtaglomerular apparatus that can regulate GFR by changing arteriolar resistance and hence blood flow and pressure into the glomerular capillaries. Renin is the rate-limiting step in the activation of the reninangiotensin system, a key modulator of body fluid homeostasis [57]. In rats, TGF activation suppresses renin secretion and resets TGF rightward to accommodate increased late proximal flow [58]. Activation of the TGF system will begin afferent arteriolar vasoconstriction [59]. In accord with Chapman et al. [3], the present study showed increase in GFR in the remaining renal tissue following the nephrectomy as consequence of TGF system activation that allowing higher early distal flow rates.

Angiotensin II, as a major vasoactive agent, is responsible for physiological as well as pathophysiological effects of RAS [60]. Following nephrectomy, plasma volume will expand because of the decrease in renal excretory function [3]. Consequently, angiotensin II formation is diminished, that will attenuate afferent arteriole tone allowing an increase in glomerular pressure and filtration [3]. This mechanism can be evident in the present investigation from the significant decrease in urine volume with concomitant decline in angiotensin in $\mathrm{Nx}$ rats. Moreover, an increase or decrease in $\mathrm{Na}^{+}, \mathrm{Cl}^{-}$, and $\mathrm{K}^{+}$uptake elicits inverse changes in GFR by altering the vascular tone, predominantly of the afferent arteriole [61]. The present study recorded significant decrease in $\mathrm{Na}^{+}$uptake that may be promote marked increment in the GFR following nephrectomy in rats.

Pyramid environment effectively antagonized the renal dysfunction following nephrectomy in the presentstudy. Research on Egyptian pyramids reveals some evidence that the space within the great pyramid generate energy of electromagnetic radiations [62]. The present study showed that housing of Nx rats in the Egyptian pyramid model induced significant increase in GRF in comparison to sham and Nx rats. This increase suggested predominantly hemodynamic response and more efficient hyper filtration [35,54]. It also appears that the energy field developed within the pyramid may increase the GFR by increase in the renal blood flow that stimulate renin production and enhance RAS system that increasing sodium reuptake. Razumov et al. [63] reported that electromagnetic waves induced a marked hemodynamic action in kidney via stimulation of the circulation of the intermediary zone with an effect of redistribution of the intra-renal blood flow.

\section{Conclusion}

In conclusion, pyramid environment reversed the actions of nephrectomy in rats and restored the kidney dysfunction near the sham levels. The present study recommends using pyramidal shapes for nephrectomized patient's rooms immediately following the surgery and during the recovery periods to avoid kidney impairment as consequence of nephrectomy process.

\section{References}

1. Barcellos FC, SantosI S, Umpierre D, Bohlke M, Hallal PC (2015) Effects of exercise in the whole spectrum of chronic kidney disease: a systematic review. J Clin Kidney 8(6): 753-765. 


\section{Journal of Complementary Medicine \& Alternative Healthcare}

2. Amoako YA, Laryea DO, Addo GB, Andoh H, Awuku YA (2014) Clinical and demographic characteristics of chronic kidney disease patients in a tertiary facility in Ghana. Pan Afr Med J 18: 274.

3. Chapman D, Moore R, Klarenbach S, Braam B (2010) Residual renal function after partial or radical nephrectomy for renal cell carcinoma. J Can Uro 4(5): 337-343.

4. Kwon T H, Frøkiaer J, Fernández-Llama P, Maunsbach A B, Knepper MA, Nielsen S (1999) Altered expression of Na transporters NHE-3, NaPi-II, Na-K-ATPase, BSC-1, and TSC in CRF rat kidneys. Am J Physiol 277(2 Pt 2): F257-270.

5. Gava AL, Freitas FPS, Balarini CM, Vasque EC, Meyrelles SS (2012) Effects of 5/6 nephrectomy on renal function and blood pressure in mice. Int J Physiol Pathophysiol Pharmacol 4(3): 167-173.

6. Levey AS, de Jong PE, Coresh J El Nahas M, Astor BC, Matsushita K, et al (2011) The definition, classification, and prognosis of chronic kidney disease: a KDIGO Controversies Conference report. Kidney Int 80(1): 17-28.

7. Río S D, Barber E, Menéndez S, Concepciónand A, Bacallao J (2013) Ozone: A Possible Agent that Delays the Chronic Renal Failure. Institute of Basic and Preclinical Sciences, Havana, Cuba.

8. Hamilton SKD, Stewart GD, McNeill SA, Riddick ACP, Phelps RR (2014) Renal Function after Unilateral Nephrectomy. J Sco Uni Med 3(2) 22-31.

9. Levey AS, Coresh J (2012) Chronic kidney disease. Lancet 379(9811): 165-180.

10. Lopes GS, Lemos CCS, Mandarim-de-Lacerda CA, Bregman R (2004) Effect of unilateral nephrectomy on renal function of diabetic rats Histol Histopathol 19(4): 1085-1088.

11. Katsuda Y, Kemmochi Y, Maki M, Sano R, Toriniwa Y, et al. (2014) Effects of Unilateral Nephrectomy on Renal Function in Male Spontaneously Diabetic Torii Fatty Rats: A Novel Obese Type 2 Diabetic Model. J of Diabetes Res 2014(2014): 363126.

12. Kaufman JM, Dimeola HJ, Siegel NJ, Lytton B, Kashgarian M, et al. (1974) Compensatory adaptation of structure and function following progressive renal ablation. Kidney Int 6(1): 10-17.

13. Brewster UC, Mark MD, Perazella A (2004) Cardiorenal effects of ReninAngiotensin-Aldosterone System. Clin Rev Art, p. 11-20.

14. Siragy HM, Carey RM (2010) Role of the Intrarenal Renin-AngiotensinAldosterone System in Chronic Kidney Disease. Am J Nephrol 31(6): 541-550.

15. Kelly TN, Raj D, Rahman M, Kretzler M, Kallem RR, et al. (2015) The role of renin-angiotensin-aldosterone system genes in the progression of chronic kidney disease: findings from the Chronic Renal Insufficiency Cohort (CRIC) study. Nephrol Dial Transplant 30(10): 1711-1718.

16. Surekha K (2011) Influence of Pyramid Environment on the Wound Healing Effects of Dexamethasone and Indomethacin -a Comparative Study. Asi J Pha Cli Res.

17. Prabhu K, RaoBGS, Rao KY, CollegeKM, Manipal (2013) A Comparative Study of Wound Healing in Rats within Wooden and Metallic Pyramid Models. J Hea Sci Res Int 2249: 9571.

18. Schul B, Pettit E (1975) The secret power of pyramids. ( $1^{\text {st }}$ edn), In Schul B, Pettit E (Eds.), Fawcett Gold Medal, CBS publications, New York, USA

19. Bhat S, Rao G, Murthy KD, Bhat PG (2010) Alterations in Stress Parameters in Rats Housed in a Pyramid Model - Seasonal Variations. Pha Bio Sci Int 1(2)

20. El-Abiad NM, Lotfi SA, El-Hadary AMA, Nagi GA (2010) A study on radiation energy of Pyramidal shape 1- Effect of housing within a
Pyramid model on cancer growth and some blood parameters of mice. Rad Res Appl Sci J 3(4A): 1211-1224.

21. Toth M, Nielsen G (1985) Model pyramid construction. In: Toth M, Nielsen G (Eds.), Pyramid Power, Vermont, USA, pp. 151-156.

22. Hari AR (2015) Pyramids for health and happiness. Sadhana publications, Bangalore, India, pp. 150.

23. Chen J, Lin J, Lin C (2015) Serum and urinary biomarkers for predicting acute kidney injury after partial nephrectomy. Clin Invest Med 38(3): E82-E89.

24. Bhat S, Rao G, Murthy KD, Bhat PG (2006) Housing in pyramid counteracts neuroendocrine and oxidative stress caused by chronic restraint in rats. Evid Based Complement Alternat Med 4(1): 35-42.

25. Trinder P (1951) A Rapid Method for the Determination of Sodium in Serum. 76: 596-599.

26. Sunderman FW, Sunderman FW (1958) Determination of potassium. Am J Clin Pathol 29: 95

27. Gindler M, King JD (1972) Chemical method for determination of calcium in serum. Am J Clin Pathol 58: 376.

28. Gornal AG, BardaC JW, David MM (1949) Determination of serum proteins by means of the biuret reagent. J Biol Chem 177(2): 751-766.

29. Fawcett JK, Scott JE (1960) A Rapid and precise method for the determination of urea. J Clin Path 13: 156-159.

30. Barham D, Trinder P (1972) An improved colour reagent for the determination of blood glucose by the oxidase system. Analyst 97(151): 142-145.

31. Schirmeister J (1964) Determination of creatinine in serum. Dtsch Med Wschr 89: 1940

32. Banchroft JD, Stevens A, Turner DR (1996) Theory and practice of histological techniques. ( $4^{\text {th }}$ edn), Churchil Livingstone, New York, London.

33. Sun M, Abdollah F, Bianchi M, Trinh QD, Jeldres C, et al. (2012) Treatment management of small renal masses in the 21st century: a paradigm shift. Ann Surg Oncol 19: 2380-2387.

34. Wolf G, Neilson EG (1990) Angiotensin II induces cellular hypertro-phy in cultured murine proximal tubular cells. Am J Physiol 259(5 Pt 2): F768-F777.

35. Cutajar M, Hilton R, Olsburgh J, Marks SD, Thomas DL (2015) Renal blood flow using arterial spin labelling MRI and calculated filtration fraction in healthy adult kidney donors pre-nephrectomy and postnephrectomy. Eur Radiol 25(8): 2390-2396.

36. Morgan BR, Ibrahim HN (2011) Long-term outcomes of kidney donors Curr Opin Nephrol Hypertens 20(6): 605-609.

37. Mjoen G, Hallan S, Hartmann A, Foss A, Midtvedt K, (2014) Long-term risks for kidney donors. Kidney Int 86(1): 162-167.

38. Abdellatif AM, Alsayed SA, Hassan YM (2013) Effects of Uninephrectomy on Morphological and Histological Measurements of the Remnant Kidney in a Goat (Capra hircus) Model. J Phys Pharm Adv 3(3): 94-102.

39. PalI K, Kumar MV (2011) Exploring Solid Lipid Nanoparticles For Intranasal Administration Of Streptomycin. Int J Pharma 1: 110-117.

40. Davies P, Allison AC, Haswell AD (1973) Selective release of lysosomal hydrolases from phagocytic cells by cytcchalasin B. Biochem J 134(1): 33-41.

41. Patil HA, Patel TB, Shah NJ (2013) A syllable-based framework for unit selection synthesis in 13 Indian languages. Oriental COCOSDA (International Committee for the Co-ordination and Standardization of Speech Databases and Assessment Techniques), Gurgaon, India. 
42. Voelkl J, Alzoubi K, Mamar AK, Ahmed MS, Abed M Lang (2013) Stimulation of suicidal erythrocyte death by increased extracellular phosphate concentrations. Kidney Blood Press Res 38(1): 42-51.

43. Diezi J, Michoud P, Aceves J, Giebisch G (1973) Micropuncture study of electrolyte transport across papillary collecting duct of the rat. Am J Physiol 224: 623-634.

44. Schultz DR, Volanakis JE, Arnold PI, Gottlieb NL, Sakai K, et al. (1974) Inactivation of $\mathrm{C} 1$ in rheumatoid synovial fluid, purified $\mathrm{C} 1$ and $\mathrm{C} 1$ esterase, by gold compounds. Clin Exp Immunol 17(3): 395-406.

45. Bank N and Aynedjian HS (1973) A micropuncture study of potassium excretion by the remnant kidney. J Clin Invest 52(6): 1480-1490.

46. Vanholder R, Baurmeister U, Brunet P, Cohen G, Glorieux G, et al. (2008) European Uremic Toxin Work Group. A Bench to Bedside View of Uremic Toxins. Am J Soc Nephrol 19: 863-870.

47. Kaplan LA, Szabo L, Ophenin EK (1998) Clinical Chemistry: Interpretation and Techniques. ( $3^{\text {rd }}$ edn), Philadelphia, USA.

48. McDonald SP, Maguire GP, Hoy WE (2003) Renal function and cardiovascular risk markers in a remote Australian Aboriginal community. Nephrol Dial Transplant 18(8): 1555-1561.

49. Nunan EA, Arya V, Hochhaus G, Cardoso VN, Moraes-Santos T (2004) Age effects on the pharmacokinetics of tityustoxin from Tityusserrulatus scorpion venom in rats. Braz J Med Biol Res 37(3): 385-390.

50. Orsić V, Mihalj M, Mogus M, Mihalj H, Jakić M, et al. (2011) Impaired kidney function in rats six months after unilateral nephrectomy - an old story, a new perspective. Med Glas Zenica 8: 185-191.

51. Carmines PK, Fleming JT (1990) Control of the renal microvasculature by vasoactive peptides. FASEB J 4(15): 3300-3309.

52. Darling IM, Morris ME (1991) Evaluation of «true"creatinine clearance in rats reveals extensive renal secretion. Pharm Res 8(10): 1318-1322.

53. Bohlouli A, Tarzamni MK, Zomorodi A, Abdollahifard S, Hashemi B, et al. (2010) Remnant kidney function and size in living unrelated kidney donors after nephrectomy. Saudi J of Kidney Dis Transpl 21(2): 246250 .
54. Mueller TF, Luyckx VA (2012) The Natural History of Residual Renal Function in Transplant Donors. Am J Soc Nephrol 23(9): 1462-1466.

55. Kopkan L, Cervenka L (2009) Renal interactions of renin-angiotensin system, nitric oxide and superoxide anion: implications in the pathophysiology of salt-sensitivity and hypertension. Physiol Res 58 : S55-67.

56. Ito S, Abe K (1996) Tubuloglomerular feedback. Jpn Heart J 37(2): 153163.

57. Peti-Peterdi J, Harris RC (2010) Macula densa sensing and signaling mechanisms of renin release. J Am Soc Nephrol 21(7): 1093-1096.

58. Deng A, Hammes JS, Thomson SC (2002) Hemodynamics of early tubuloglomerular feedback resetting during reduced proximal reabsorption. Kidney Int 62(6): 2136-2143.

59. Komlosi P, Bell PD, Zhang ZR (2009) Tubuloglomerular feedback mechanisms in nephron segments beyond the macula densa. Curr Opin Nephrol Hypertens 18(1): 57-62.

60. Navar LG (2004) The intrarenal renin-angiotensin system in hypertension. Kidney Int 65(4): 1522-1532.

61.SchnermannJ, Briggs JP (2000) Function of the juxtaglomerular apparatus: control of glomerular hemodynamics and renin secretion. ( $3^{\text {rd }}$ edn), In: Seldin DW (Ed.), The Kidney: Physiology and Pathophysiology, Williams L and Wilkins, Philadelphia, USA, pp. 945980.

62. Nagy GA (2007) The architectural figuration as a matrix for environmental control due to bioenergy science. Ain Shams University, Egypt, p. 67-93.

63. Razumov AN, Karpukhin IV, Kiiatkin VA, Esilevskiǔlu M, Ufimtseva AG (2001) The effect of ultra high frequency electromagnetic fields on the intrarenal blood flow and kidney morphology in pyelonephritis (experimental study). Vopr Kurortol Fizioter Lech Fiz Kult 2: 3-8.
Your next submission with JuniperPublishers will reach you the below assets

- Quality Editorial service

- Swift Peer Review

- Reprints availability

- E-prints Service

- Manuscript Podcast for convenient understanding

- Global attainment for your research

- Manuscript accessibility in different formats ( Pdf, E-pub, Full Text, Audio)

- Unceasing customer service

Track the below URL for one-step submission http://juniperpublishers.com/online-submission.php 